This item was submitted to Loughborough's Research Repository by the author.

Items in Figshare are protected by copyright, with all rights reserved, unless otherwise indicated.

\title{
An appreciative inquiry into the first export order
}

\section{PLEASE CITE THE PUBLISHED VERSION}

https://doi.org/10.1108/QMR-01-2015-0001

\section{PUBLISHER}

(C) Emerald

\section{VERSION}

VoR (Version of Record)

\section{PUBLISHER STATEMENT}

This work is made available according to the conditions of the Creative Commons Attribution-NonCommercialNoDerivatives 4.0 International (CC BY-NC-ND 4.0) licence. Full details of this licence are available at: https://creativecommons.org/licenses/by-nc-nd/4.0/

\section{LICENCE}

CC BY-NC-ND 4.0

\section{REPOSITORY RECORD}

Crick, David, and Jim Crick. 2019. "An Appreciative Inquiry into the First Export Order". figshare. https://hdl.handle.net/2134/26846. 


\section{e emeraldinsight}

\section{Qualitative Market Research: An International Journal}

An appreciative inquiry into the first export order

Dave Crick, James Crick,

\section{Article information:}

To cite this document:

Dave Crick, James Crick, (2016) "An appreciative inquiry into the first export order", Qualitative Market Research: An International Journal, Vol. 19 Issue: 1, pp.84-100, https://doi.org/10.1108/ QMR-01-2015-0001

Permanent link to this document:

https://doi.org/10.1108/QMR-01-2015-0001

Downloaded on: 04 October 2017, At: 00: 15 (PT)

References: this document contains references to 55 other documents.

To copy this document: permissions@emeraldinsight.com

The fulltext of this document has been downloaded 288 times since 2016*

\section{Users who downloaded this article also downloaded:}

(2016),"A front-to-back guide to writing a qualitative research article", Qualitative Market

Research: An International Journal, Vol. 19 Iss 1 pp. 115-121 <a href="https://doi.org/10.1108/

QMR-08-2015-0074">https://doi.org/10.1108/QMR-08-2015-0074</a>

(2016),"Marketing in a time of toxic leadership", Qualitative Market Research: An International Journal, Vol. 19 Iss 1 pp. 44-64 <a href="https://doi.org/10.1108/QMR-04-2015-0030">https:// doi.org/10.1108/QMR-04-2015-0030</a>

Access to this document was granted through an Emerald subscription provided by emeraldsrm: 327770 []

\section{For Authors}

If you would like to write for this, or any other Emerald publication, then please use our Emerald for Authors service information about how to choose which publication to write for and submission guidelines are available for all. Please visit www. emeraldinsight. com/ authors for more information.

\section{About Emerald www.emeraldinsight.com}

Emerald is a global publisher linking research and practice to the benefit of society. The company manages a portfolio of more than 290 journals and over 2,350 books and book series volumes, as well as providing an extensive range of online products and additional customer resources and services.

Emerald is both COUNTER 4 and TRANSFER compliant. The organization is a partner of the Committee on Publication Ethics (COPE) and also works with Portico and the LOCKSS initiative for digital archive preservation.

*Related content and download information correct at time of download. 
QMR

19,1

\section{4}

Received 2 January 2015

Revised 17 April 2015

Accepted 14 May 2015

\section{An appreciative inquiry into the first export order}

\author{
Dave Crick
}

Marketing and International Business, Victoria University of Wellington, Wellington, New Zealand and Telfer School of Management, University of Ottawa, Ottawa, Canada, and

James Crick

Loughborough University, Leicester, UK

\begin{abstract}
Purpose - This study aims to report on an investigation into decision-making leading to a UK firm's first export order. It demonstrates the application of appreciative inquiry (AI) as an underutilised research method in marketing investigations.

Design/methodology/approach - An AI research approach was undertaken in a firm that had not started exporting at the commencement of the study whereby the interventionist approach allowed the management team to overcome negative perceptions in their decision-making. From a research perspective, marketing decision-making could be understood in real time as opposed to in hindsight.

Findings - While the key decision-maker is likely to be the owner/manager in small newly internationalising firms, a variety of factors will affect the decision to start exporting including the influence of the management team. In particular, the management team's perceptions towards a combination of effectuation- and causation-based decision-making where risk/reward considerations in exploiting various international marketing opportunities are undertaken in light of perceived affordable losses, as well as against evolving objectives.

Originality/value - The contribution is to demonstrate the AI methodology, which to date has received attention in management domains other than marketing; it offers an interventionist approach to help managers overcome barriers and move positively forward in decision-making. It offers researchers an opportunity to understand marketing decision-making in real time.
\end{abstract}

Keywords Marketing, Appreciative inquiry, Export, Internationalisation

Paper type Research paper

\section{Introduction}

Approximately 50 years ago, Simmonds and Smith's (1968) classic study investigated issues regarding “what lies behind a firm's first export order?” Subsequently, a good deal of literature has addressed issues associated with decision-making with respect to firms' internationalisation (Andersson, 2011; Gabrielsson and Gabrielsson, 2013; Kalinic et al., 2014; Crick and Crick, 2014, 2015). This investigation reports on a single case study involving the utilisation of an interventionist approach that has been underutilised in the marketing literature. As such, decision-making is considered in real time as opposed to in hindsight. The research objective of this study is to understand issues that contribute to the holistic nature of decision-making with respect to the first order from overseas, that is, via the application of appreciative inquiry (AI).

At the start of the study, the management team members in the case study firm were looking to internationalise owing to potential benefits that were recognised, but were
Qualitative Market Research: An International Journal Vol. 19 No. 1, 2016 pp. $84-100$

C Emerald Group Publishing Limited 1352-2752

DOI 10.1108/QMR-01-2015-0001 
being held back because of perceived barriers. The study contributes to the literature at the international marketing-entrepreneurship interface by following an AI qualitative methodological approach, leading to an understanding of what lies behind a firm's decision to internationalise. Therefore, it demonstrates the application of an interventionist methodology that is more widely used in other academic disciplines, i.e. offering opportunities for marketing academics and practitioners to consider adopting the research approach.

In terms of the format of this paper, it starts by introducing the AI methodological approach providing an overview for researchers in the marketing discipline that are unfamiliar with its use. Issues in its wider application of research involving change are then considered before the specific use in the current investigation is considered. Subsequently, the methodological approach used in the study is considered. This is followed by the findings that lead to the interventionist approach in the context of a single firm to demonstrate the application of AI, i.e. to understand the process resulting in a management team undertaking their first international order. The paper ends with a discussion involving conclusions, implications and areas for further research.

\section{AI as an innovative methodology in marketing}

The use of AI is far from new having been utilised for over 25 years in various academic disciplines (Cooperrider and Srivastva, 1987). However, it appears to be lacking in use within the marketing domain, hence, providing an opportunity to demonstrate its application as an innovative methodological approach in undertaking research in the subject area, specifically, within an international marketing context. This lack of utilisation is perhaps not surprising given that understanding aspects of change within an organisation's marketing practices in an interventionist sense, i.e. where the researcher is a facilitator in the process, has not been a key research focus in studies to date. Interest has instead focused on managers' recollection of events in a discursive sense such as via interviews, or numerically, for example, via statistically based questionnaires (Andersen, 1993; Coviello and McAuley, 1999; Jones et al., 2011). Furthermore, access to data collection via AI may be difficult; even where it can be applied, it may be considered to contain a potential inherent bias owing to the interventionist nature adopted. Therefore, an understanding of the AI approach is useful.

AI has certain similarities with the more widely known action research (AR) approach; that is, both are often associated with intervention and change management. Coghlan and Brannick (2001) discuss the issue of "knowledge transfer" as part of the interventionist research focus. AR practitioners and members of organisations establish a co-research agenda to analyse, implement and evaluate systems of change (Cady and Caster, 2000). Nevertheless, AI is different to AR in the sense that questions and the process followed are positively oriented to move the research forward (Hammond and Royal, 2001). In fact, this more positive, real-time and cooperative intervention can help alleviate conflict and resistance to change among participants (Bushe and Kassam, 2005).

The format for AI research is shown in Figure 1. The topic choice to be addressed and the way the process is undertaken needs to be phrased in an affirmative manner to participants. Cooperrider and Whitney (2001, p. 20) note that "the seeds of change are implicit in the very first questions we ask". In a marketing context, applications for 
QMR

19,1

\section{6}

Figure 1.

AI 4D approach based on Cooperrider and Srivastva (1987)

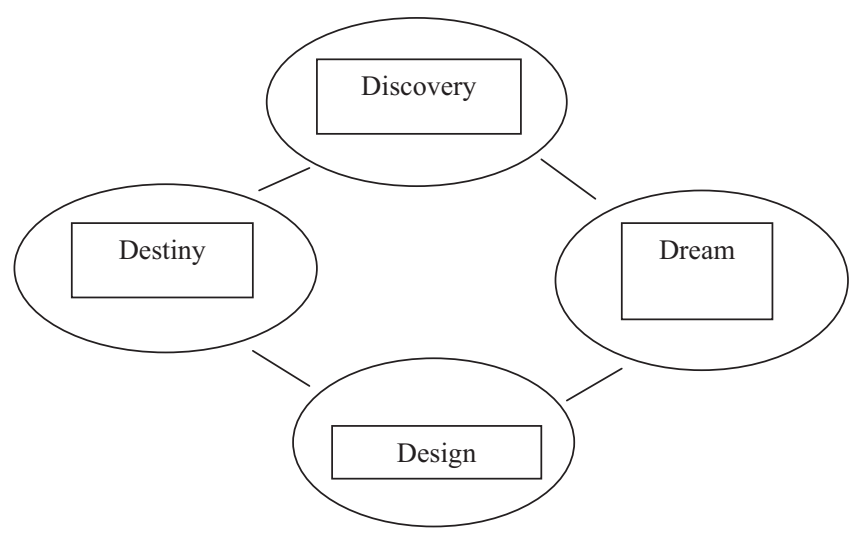

using an interventionist methodology to facilitate change, e.g. to address critical incidents or overcome negative perceptions, can be vast. To demonstrate this in simply one example, having even a neutral phrasing of questions around a topic such as the "perceived barriers in exporting and available government assistance" may potentially lead to reinforcing already held views. Indeed, a review of the literature involving the issue of export barriers and assistance would arguably suggest, in some cases, negative perceptions about the support on offer to assist managers to overcome barriers (Freixanet, 2011; Leonidou et al., 2011; Durmusoglu et al., 2012).

Therefore, to pose questions in a way that allows dwelling on participants' negative initial/pre-existing views can reinforce perceptions. This may be acceptable for studies where the objective is to report simply on perceptions, but not one where the objective of intervention is to facilitate change. Following the example through an affirmative interventionist approach to the topic may be to ask the initial question - what positive views do the management team have about export assistance to help overcome barriers? The range of answers may be vast; however, in the example provided, even if negative perceptions exist, the positive slant may facilitate affirmative discourse around potential assistance tailored to a firm, how it has helped other firms, etc. By then, following the AI process in Figure 1, the interventionist objective may be to change initial negative perceptions to move the firm forward. Consequently, in the context provided, the management team may actually become more aware of, or use the support with, the view of facilitating internationalisation.

AI does not set out to be a diagnostic methodological tool with the aim of "curing" the problems/symptoms of an organisation. Instead, it focuses on inspiring participants to co-create a future way forward, e.g. by building on positive prior experiences up to the current point of intervention. Cooperrider and Whitney (1999) argue that AI involves asking questions to strengthen a system's capability to heighten positive potential, that intervention gives a way to innovation and that instead of negation, there is discovery.

This co-created process, therefore, means that the researcher helps in an interventionist sense to subsequently move the firm forward as part of the process something arguably rare in the wider (international) marketing domain unless a researcher is acting in a training/consultancy capacity. Examples exist to demonstrate this such as Piercy's (1991) "Market Led Strategic Change" that has a text and 
supporting material to assist managers take their firms forward, either domestically or overseas depending on managers' objectives, resources, capabilities, etc. The potential for problems can arise when research is undertaken in parallel with training and/or consultancy with respect to the distinction between activities, and hence, the need to follow clear protocols in terms of data collection and participants' approval in using AI.

After commencing with an affirmative topic choice (or placing a positive viewpoint on a potentially negatively associated topic), AI moves into the discovery part of the process that involves participants considering the "best of what is" regarding positive elements of the firm, e.g. what works well. They then move to the dream phase whereby those positive aspects in the discovery phase are built upon to envision practices that could realistically work well in the future. The design phase is then entered where the participants engage in dialogue to compile positive "possibility" statements regarding their future vision, including priorities. Finally, in the destiny phase, participants develop action plans to convert their vision into a workable reality. In the case of international marketing, it could, therefore, have applications like helping managers to take their first move into overseas markets, i.e. the issue demonstrated in this current investigation.

AI, like any methodological approach, has positive and negative features. In a positive sense, it is change oriented in real time, iterative, plus action and reflection oriented; therefore, concerned with making improvements with respect to current practices rather than simply reporting them without the intention of moving an organisation forward. Nevertheless, being "values" oriented, the philosophical perspective of researchers is, therefore, important to help avoid problems (Bushe and Kassam, 2005). Following a social constructionist perspective might indicate what we believe as true influences what we do; therefore, thought processes and actions emerge from interactions. AI can add value to help participants arrive at new ideas that lead to actions, but the researcher needs to avoid personal biases in the methodology, acting as a facilitator in data collection.

\section{Application of $\mathrm{AI}$ in researching aspects of change}

Cooperrider and Srivastva (1987, p. 139) suggest that "social order is a subject matter capable of infinite variation through the linkage of ideas and action". This has implications for researchers collecting data in real time where events can unfold, i.e. based on the changing thought processes of decision makers. When faced with multiple opportunities, some are pursued and not others, but collecting data after the event may not capture these issues.

AI can be used in a number of change management research situations and, depending on the nature of firm plus the issue potentially in need of change, can involve the entire organisation (Murrell, 1999). However, in very small firms including new venture start-ups, the owner/manager may, in fact, be representative as a key informant with respect to decision-making as layers of hierarchy are less likely to exist (Carson et al., 1995), or at the very least, the owner/manager will be part of a small management team. Using one as opposed to multiple respondents in an organisation provides a potential bias. AI is considered to help alleviate resistance to change; therefore, change management research approaches that engage all the key decision makers in very small organisations arguably have benefits owing to their multiple perspectives.
Inquiry into the first export order 
QMR

19,1

\section{Specific context of the study}

Much has been written in the literature at the international marketingentrepreneurship interface with respect to internationalisation decisions, i.e. barriers, stimuli, processes undertaken, etc. (Bilkey, 1978; Aaby and Slater, 1989; Miesenbock, 1988; Andersen, 1993; Coviello and McAuley, 1999; Jones et al., 2011). However, this investigation focuses on decision-making with respect to the initial decision to internationalise and draws on the research of Sarasvathy (2001) who discusses causation versus effectuation approaches; this is consistent with recent studies (Andersson, 2011; Gabrielsson and Gabrielsson, 2013; Crick and Crick, 2014; Kalinic et al., 2014). Causation-based decision-making assumes that a manager may start with a number of alternatives and end up with one objective; however, an effectuation approach suggests that a manager accepts that these alternatives may end in different results. Risk/reward decisions are likely to vary depending on perceptions of "affordable losses" (Sarasvathy, 2001) and on the objectives management teams set (Crick and Spence, 2005).

It has been long established that the characteristics of the management team, broadly defined to include their experience and motivation, are key to influencing their respective firm's export development (Leonidou et al., 1998; Acedo and Galan, 2011; Kuppusamy and Anantharaman, 2012). The way in which respective management teams react to export barriers that are perceived or actual; also, stimuli that are internal or external to the firm, plus that are proactive or reactive in nature, are likely to vary (Leonidou, 1995; Morgan, 1997; Leonidou et al., 2007; Kahiya, 2013).

The speed, scale and scope of a firm's internationalisation process is likely to be affected by various circumstances. First, a management team's respective resources (Autio et al., 2000; Westhead et al., 2001). The resource-based view (RBV) suggests that businesses are able to derive competitive advantages from resources and/or capabilities (Barney, 2001, 2014); this has led to the "value, rarity, imitability and ownership" framework with respect to competitive advantages. Second, both social- and business-related networks (Welch and Welch, 1996, 2004); these may be viewed as potential intangible resources that are related to the RBV, although studies tend to draw out networks as a separate but related perspective. Third, a contingency perspective has been offered (Ibeh, 2003) whereby strategies are formulated in the context of various circumstances and not least industry-based considerations (Bell et al., 2004), plus institutional factors associated with the market(s) targeted (Freeman et al., 2012).

Studies to date have largely followed both quantitative and qualitative methodologies that are reliant on managers' recall of events after (in some cases, a long time after) the first overseas order was accepted and answers are reported in hindsight. Despite potential bias, an interventionist approach offers an innovative approach in understanding the initial step on the internationalisation process by helping to facilitate change. Studies have suggested a holistic perspective be taken when investigating various management teams' internationalisation strategies (Jones, 1999; Crick and Jones, 2000; Ibeh, 2003; Jones and Coviello, 2005), i.e. a combination of factors are likely to help explain the decisions undertaken including the first step. As such, it is worth repeating the research objective of this study, i.e. to understand issues contributing to the holistic nature of decision-making with respect to the first order from overseas, that is, in real time via the application of AI. 


\section{Methodology}

As a database of firms considering commencing their internationalisation process was not available in the course of this study, it was not possible to establish the total number of firms in this population or a starting point to recruit participants. The five members of the management team (the only employees) in this study were recruited via their participation in a business development programme in the first year of their firm's inception, and as such, the start-up firm was less than one year old at the time of the AI research. Based on the criterion of number of employees, it would be termed a "micro-firm" having less than ten staff (Storey, 1994) involving a high-tech development with potential applications to several sub-sectors. Being a start-up firm, there were no past strategies to refer back to that were directly related to the business except those related to the experience of the five members of the management team based on prior employment. Therefore, industry experience was present within the management team including networks from earlier roles elsewhere. This included other experience in the sector but also selected country knowledge in prior employment. While these managers held functional roles related in their job titles, e.g. marketing, finance, etc., in reality, the start-up nature of the firm meant that some roles overlapped and not least with respect to the key decision maker who ultimately made strategic decisions.

The investigation involves what Stake (1995) views as an "instrumental case study", i.e. that focuses on a particular issue or problem and which identifies a case to explore this. The "boundary" of the case study was restricted to the small management team involved in the business start-up rather than external stakeholders like members of networks due to the nature of the data being collected using the AI approach. Triangulation of data (where possible) was, therefore, set within this specified boundary; secondary data were limited being a start-up firm but involved non-confidential documents. Observation was undertaken with respect to the interaction being members of the management team during scheduled meetings and especially with respect to the way decisions were being made.

The AI approach included participation from the whole management team to allow both depth of data collected and avoidance of the use of a key respondent that would be inappropriate for AI to be implemented. All members participated in meetings and the duration of time involved varied at particular phases of the investigation, but this ranged over three months. Managers were asked to keep notes between meetings, although owing to the day-to-day pressures of running a business this was in reality somewhat limited. At the time of recruitment to the study, the management team members had not engaged in overseas sales but were actively looking to do so. In recognising potential bias, the facilitation of change management is different to participating in what may arguably be termed as a "conventional" research project (where, as previously mentioned, events are normally recalled rather than in real time); however, in this study, one aspect led to the other in terms of the interventionist AI approach. This potential for bias was offset by the ability to recruit an organisation that involved a management team willing and able to discuss considerations leading to their first order from overseas as decisions unfolded, whereby the researcher acted as a facilitator not decision maker.

Utilisation of the AI approach helped provide detailed and holistic knowledge (Eriksson and Kovalainen, 2008) utilising various sources of context-rich data. This included internal documentation through to different managers' inputs to offer validity 
QMR

19,1

90 in the process. Sinkovics and Alfoldi (2012) suggest that qualitative research is sometimes presented in a linear manner, wrongly suggesting deductive reasoning; the approach undertaken in this study was more "iterative" in nature. Notes were shared with the management team to aid reliability, record thought processes plus support the "trustworthiness" of the data (Sinkovics et al., 2008). The iteration meant that "progressive focusing" was utilised in line with Stake (1995), specifically, involving an iteration between theory and the evolving data.

Sinkovics et al. (2005) highlight problems in analysing data. During the application of $\mathrm{AI}$, various meetings were undertaken with members of the management team on separate occasions to enable a period of reflection. Within the boundary of the single instrumental case study, the approach undertaken is best represented as somewhere between what Welch et al. (2011) term "interpretive sensemaking" and "contextualised explanation" in Figure 2, but with an emphasis on the former. That is, the study is strong in context, but stronger in some aspects of causal explanation than others, owing to the nature of the way the investigation was undertaken. To be consistent with Stake (1995), "particularisation" was the goal of the research. The context, narratives and personal engagement undertaken were accounted for and establishing cause-effect relationships was not the aim; rather, an appreciation of the social context was important.

The management team members were briefed about how AI would run, i.e. the four-dimensional (4D) process in Figure 1. While the affirmative aspect of AI built on the management team's strengths, e.g. experience and networks, ways of working were also challenged in a positive manner to provide a platform to move forward. It was, therefore, important that each member of the management team had their voice heard among colleagues. Therefore, AI enabled evolving objectives and strategies to be set. As a methodological tool, it enabled the understanding of the thought processes and dynamics between members of the management team to be elicited.

One way to present the data in the section that follows would be to draw heavily on notes of what was discussed and the manner in which this took place, the idea to be non-positivist in the approach taken as an argument would not be made for objectivity (Tadajewski, 2010). In effect, understanding issues in the management team's own words might be considered useful. Instead, because the purpose of this study is to demonstrate the application of the AI methodology, there is a concentration on "process" issues as opposed to managerial discourse that may be distracting given the multiple discussions undertaken. This is especially significant, given that as previously mentioned, the interaction with the management team varied at different stages to allow them to operate their business in addition to the time spent facilitating change. It would

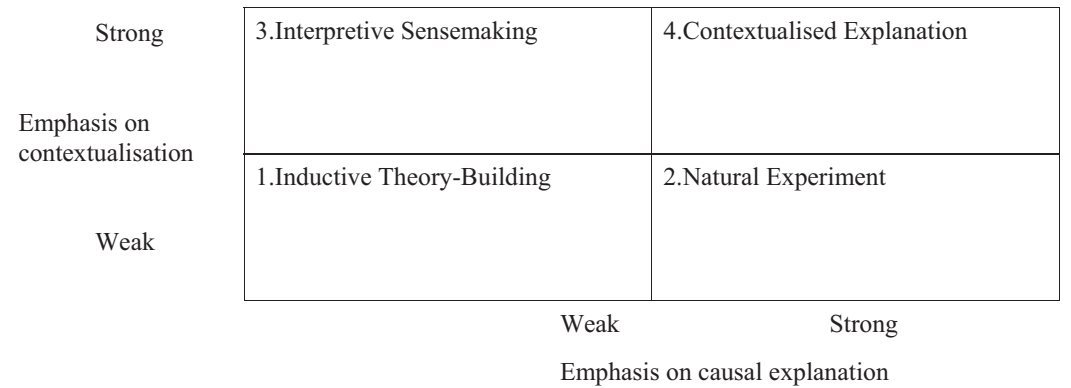

Figure 2.

Welch et al.'s (2011) 4 methods framework of theorising from case studies 
not be possible to be with the management team constantly (Andersson and Floren, 2011).

\section{Findings: application of AI}

The application of AI is used in this study to demonstrate a management team's move in risk/reward perceptions about internationalising from a somewhat negative (or at least reluctant) stance to one that was more positive and helped facilitate the decision to accept the first order from overseas. The process is shown in Figure 3. Intervention (or subjects of inquiry) involved questions based on knowledge from existing studies, plus associated experience with management teams, involving the holistic nature of factors affecting decision-making with respect to internationalisation. For example, what research had the managers undertaken or what knowledge/experience could they draw upon with respect to issues associated with demand, competition, differentiation, adaptation, capabilities to address perceived challenges, etc.; in addition, the extent to which factors may vary across overseas markets that might be of potential. Specifically, questions were formulated from knowledge associated with the holistic nature of factors affecting internationalisation, namely, the RBV including networks; also, contingency issues, e.g. industry-based factors, plus the institutional perspective of serving a different market(s). However, the exact nature of the subjects of inquiry was different at each stage, and these will be considered individually.

The initial discussion involved the benefits in a move to commence the internationalisation process, i.e. a positive intervention to reduce the negative associations with perceived barriers that were prevalent at that stage. From the outset, it should be emphasised that exporting was the management team's preferred market entry mode based on risk/reward considerations as opposed to alternatives such as licensing, joint ventures, subsidiaries, etc. Initial negative perceptions were around the risk of selling internationally when the start-up capital had left the owner/manager with considerable debt including collateral against that debt. Nevertheless, exporting was a relatively low-risk mechanism for market entry with ease of exit if things went wrong, i.e. as a risk-minimisation strategy. The whole management team at the initial stage realised that their domestic market was limited; hence, internationalising was needed at some stage to grow the business and likewise earn money, but there were limited funds to make this happen.

However, from a positive perspective, the potential rewards associated with making the venture successful went some way to offset the perceived risks involved; not least equity shares and in particular for the key decision maker who was the major equity holder. Although factors were discussed in more detail at the discovery phase, the small management team perceived that they knew a good deal about how the industry worked, which markets to target (although were concerned about institutional ways of doing business such as legal requirements overseas), they had networks, plus offered a differentiated product that would be positively received internationally. Consequently, the management team's core aim was to use their resources in the most appropriate manner (including if there was a need to raise more funds); in turn, this was influenced by the perception of what was an affordable loss if things went wrong.

Discussion in an AI context is by its very nature focused on positive issues, and therefore, negative factors such as the notion of "affordable losses" were framed in an upbeat manner. As such, the nature of potential rewards and making this realisable in
Inquiry into the first export order 
QMR

19,1

92

Figure 3.

Interventions Using AI
Starting point: understanding the need to positively move forward.

Key issues found to be holding managers back: i.e. resource risks such as limited finances and priorities on how these should be spent; institutional risks of overseas markets; risk of collateral against debt.

Stage 1: understanding current strengths.

Key issues in firm: e.g. managerial aspirations; management knowledge of sector; learning from prior employment; networks; possibility of extra finance.

Stage 2: envision aspirations.

Key issues: e.g. serve lead markets; reputation in sector; financially stable.

Stage 3: design of possibility plans to meet aspirations.

Key issues: such as where to target (markets); who (develop/expand networks); how (speed, capacity implications e.g. expand or outsource etc.); what else is needed.

Stage 4: action plans to move forward

Key issues: e.g. need to renegotiate financing; explore government assistance; prioritise and focus on target market; not expand too quickly.

End point: review of process.

Key issues: learning (what worked and did not work); is this knowledge transferable?

planning was more important and likewise how the AI process might work to consider what mechanisms could be put in place to reduce the impact of things going wrong, i.e. to make issues affordable in the start-up firm. For example, this influenced the previously mentioned initial preferred entry mode of exporting to allow ease of market entry and exit. 
The discovery phase of the process involved the management team being asked questions to consider the "best of what is". Here, the skill and knowledge base of the management team was considered, not just in terms of prior international experience (roles before the new start-up firm), but rather more widely building on the features uncovered in the initial stage. For example, positive issues around the previously mentioned knowledge plus what had worked well before in earlier employment; in addition, even if things had not worked well before (e.g. broad institutional issues related to prior experience), what learning arose from these experiences to help the current firm?

Prior learning from previous employment had, in the first instance, enabled an opportunity to be identified in the market that the management team believed could be exploited based on factors such as demand through to differentiation versus competitors. Based on prior experience in salaried roles, networks had been developed in various countries at different parts of the supply chain. For example, this ranged from knowledge of potential suppliers through to likely intermediaries that might best represent the firm in key markets that were viewed as having the most potential, plus able to advise on local market requirements. As such, trust had been developed within networks that reduced perceived risks in comparison to potential rewards. Furthermore, from an administrative perspective, prior roles in salaried positions had enabled members of the management team to learn from the experience of dealing with matters ranging from hedging of exchange rates and administration of payment terms (insurance, documentation, etc.) through to logistical matters relating to supplying overseas markets.

This enabled positive considerations around issues such as the RBV including networks, the industry based factors and the institutional view to be undertaken. This interaction among the management team developed into a consideration of broader positive issues. Despite being a resource-constrained firm, negative issues were turned around to a positive focus such as could further resources be obtained if necessary and from which sources (plus implications, e.g. losing equity and what would investors allow funds to be spent on)?

A further key positive consideration was whether based on all these issues, if the current perceptions about selling overseas were really things that could be overcome; this took the process to the dream phase. Here, affirmative aspects in the discovery stage were developed in questions to enable the management team to imagine their future (within realistic parameters and especially noting the restricted budget). For example, if the management team could visualise where they would be in five years' time - what would this look like?

Instead of specific objectives being set to guide strategies, a broad vision was envisaged. This was necessary to guide the next stage of the process because alternative paths could be imagined. For example, did the senior management team want to get the firm into a saleable position if not have actually developed and sold the firm by that stage? Alternatively, did the management team envisage a longer-term relationship with the firm, and if so, how was that viewed? At this stage, the key considerations were an imagined dominance in major markets in the triad regions of North America, Europe and Asia, specifically, in terms of market share. Furthermore, an aim would be that the firm would have an excellent international reputation generally (meaning a quality 
QMR 19,1

offering with associated customer service). A final consideration was that the firm should be financially stable with low debt.

After this, there was a period of reflection before the design phase was entered; here, the management team were asked to compile positive "possibility" statements regarding their future vision. Very fluid objectives were discussed that could easily be amended to evolve in the light of changing circumstances to meet the broad vision of where the management team wanted the firm to be. These discussions utilised the knowledge discussed so far with the view of taking the firm onto the internationalisation path. Risk/reward considerations with respect to affordable losses were especially important. For example, the rewards associated with growing the business, profits and making it saleable had to be balanced with various risks. These included business risks like non-payment and reputational risks such as poor quality or service perceptions in the market. Additionally, personal risks to the management team and not least the owner/manager in terms of losing their investment and the collateral against debt. In such circumstances, perceptions of affordable losses were influenced by decisions regarding growing the business (including overseas) but not at a pace where expansion could not be adequately resourced.

With respect to the key perceived barrier of the management team having recognised resource constraints being a start-up business, it was no point taking on an order that was so large that it would harm the firm because of a shortage of working capital. Moreover, based on capabilities, the lead time had to be feasible. Owing to a perceived current lack of market access, it was decided that certain countries should not be targeted, and instead, preference should be given to those with potential but easier access due to existing networks. Furthermore, the perceived lead markets in the sector should be given preference and access was needed, most notably the USA, as this was viewed as the "lead market" because of demand and being a reference point for other countries. In short, being aware of limitations allowed a positive perspective to be put on issues and, in turn, to determine what was possible based on being alert to opportunities being presented. The owner/manager in particular was clear on what was perceived as an affordable loss and the rest of the management team were equally clear on what objectives were set (albeit they were quite fluid in nature), the funds available and the need to set in motion a series of workable strategies.

Finally, before the end point when the process was reviewed, the process moved to the destiny phase that involved the implementation of the design stage considerations. The management team were, therefore, questioned on the development of an action plan to convert their vision into a workable reality, i.e. strategies to meet the evolving goals. Various scenarios were played out using a "what if" facilitation technique to account for potential contingencies; however, that is not to suggest that the facilitation can identify all scenarios. Positive avenues pursued included seeking assistance, intermediaries in preferred markets, obtaining further financing from various sources and extending the workforce to develop the skills and capabilities. Importantly, this had to be endorsed by the key owner/manager that would have the overall decision-making authority plus who carried risk/reward perceptions towards the previously mentioned affordable losses if things went wrong.

This stage was more iterative than the earlier three, as it needed intervention to develop an action plan that was, in fact, workable and which the management team and especially owner/manager felt comfortable with. The end result was that the firm 
received additional financing to allow it to follow the strategies discussed in the AI process. It subsequently received its first order from overseas via targeting the USA, i.e. an overseas market deemed preferable based on risk/reward factors to the management team, including the size and contract conditions of that order. This was in addition to being the perceived "lead market" and as such a reference point for other countries. The review of the process (including what had/had not worked) suggested that it had engaged the management team including receiving the endorsement of the owner/manager and negative perceptions were turned around. Key thought processes in risk/reward decisions thus far could assist in formulating the management team's continuing evolving objectives.

\section{Discussion}

It has been approximately 50 years since Simmonds and Smith's (1968) classic study investigating issues surrounding "what lies behind a firm's first export order?" Studies have subsequently addressed issues associated with decision-making with respect to firms' internationalisation and not least advocated an effectuation lens to help explain risk/reward considerations (Andersson, 2011; Gabrielsson and Gabrielsson, 2013; Kalinic et al., 2014; Crick and Crick, 2014, 2015).

The objective of this study was to understand issues contributing to the holistic nature of decision-making with respect to the first internationalisation decision and specifically in real time via the application of AI as an underutilised methodological approach in the broader marketing domain. This was in the context of an instrumental case study (Stake, 1995) of a start-up firm. While the AI approach is not innovative having been in operation for over 25 years (Cooperrider and Srivastva, 1987), arguably, it is innovative in the marketing context to offer a real-time perspective as opposed to relying on answers made in hindsight. Conclusions and implications were derived from this study that can now be discussed.

\section{Conclusions}

The first conclusion of this study is to support earlier research, namely, that no single factor could fully explain the initiation of a firm's internationalisation process, suggesting a holistic approach be undertaken in studies of this nature. In other words, a combination of factors interact to varying degrees with respect to an individual management team's decision-making (Jones, 1999; Crick and Jones, 2000; Ibeh, 2003; Bell et al., 2004). This will be in the context of the objectives that are set (Crick and Spence, 2005). Specifically, a combination of resource-related (including networks) factors, balanced with contingency-based issues associated with the industry and institutional environments the firm operates within, will affect managerial decision-making. With respect to this conclusion drawn from a single case study, arguably, research investigations that report managerial perceptions after the event may not capture the dynamic inter-play between factors shaping decision-making or may suffer from responses being made in hindsight.

It can secondly be concluded that a combination of causation and effectuation based decision-making is likely to exist in planning, and the two should not be seen as dichotomous. Specifically, decision makers may be easily able to articulate a broad direction in which they want to head, i.e. in line with a causation-based approach. In reality, a series of decisions will be traded off as risk/reward considerations in the form
Inquiry into the first export order 
QMR 19,1

of perceptions of affordable losses in heading towards that broad goal, i.e. more consistent with an effectuation-based approach (Sarasvathy, 2001). As such, the managerial objectives that Crick and Spence (2005) refer to are likely to evolve with respect to the start and continuation of a firm's internationalisation process. Specifically, as opportunities are identified, some are exploited, whereas others are not based on risk/reward factors. Related to this second conclusion is that studies undertaken in real time go some way towards understanding this evolving process.

\section{Implications}

The implication arising from this study is to suggest that the application of the AI approach, therefore, has potential benefits to research in the domain of marketing whereby a focus of investigations would be to understand a key aspect of change within an organisation around or at the time that it happens rather than to rely on participants' recall of events. This depends on the frequency of contact with the owner/manager and management team over the period of study, given that researchers cannot be at their side 24 hours a day and even shadowing managers will only provide a partial understanding of how they spend their time (Andersson and Floren, 2011).

In the case of the current investigation, this involved a firm's first order from overseas where its acceptance had implications for the management team with respect to a change in practices to take the firm along the first steps in the internationalisation process. Consequently, related to this implication is that the approach can also be used by consultants and policymakers to assist change management processes in firms' marketing activities, albeit care must be taken in its application under such circumstances not to mix consultancy with research (the distinction in this study being that consultancy is paid for by the recipient, whereas research is not)! With respect to this distinction, boundaries must be set regarding the nature of interventions undertaken, e.g. purpose, are interventions agreed or dictated, is this as a result of payment for the interventionist advice, etc. It is emphasised that the feasibility of using $\mathrm{AI}$ is based on the open and full participation of the management team.

Furthermore, if the firm is paying for consultancy, it stands to reason that decision makers are more likely to maintain momentum in the process to add value to their firm. This is more difficult in a pure research study unless the added value to a management team can be articulated. For example, this is likely to be based on the credibility of those involved in facilitating the process to add value in some way, such as their track record with working with similar firms and their perceived professional standing in a given academic and business community. In the case of this current research study, this might involve a perceived track record of working with start-up firms in entrepreneurship hubs, business incubators, etc.

\section{Areas for future research}

AI offers many opportunities to explore aspects of change in the wider research domain of marketing and not just at the interface with international entrepreneurship reported in this study. Nevertheless, recent literature reviews such as Jones et al. (2011) outline various avenues for future research at the international entrepreneurship-marketing interface that may take this specific study forward; some of these may open opportunities for the application of an interventionist approach such as AI. In fact, critical incidents may affect or be influenced by various aspects of managerial 
behaviour (Bell et al., 2004) and strategies will change over time (Jones and Coviello, 2005). Consequently, "real-time" perspectives on decision-making offer an opportunity to further our understanding of process based issues using a more innovative methodology.

However, the approach is not without its limitations and, as previously mentioned, is especially contingent on obtaining participation that may in reality be problematic (particularly depending on the timeframe involved). In fact, this may also be contingent on the perceived credibility of the researcher(s) conducting the AI study to interact with a management team. Furthermore, it is likely that case studies will be very context-specific, and hence, generalisation across cases may be difficult, if that is required. Despite potential bias, the approach may help move the marketing literature forward by offering a different perspective to managers recalling issues after (in some cases, long after) an event and indeed reflecting in hindsight.

\section{References}

Aaby, N-E. and Slater, S.F. (1989), "Management influences on export performance: a review of the empirical literature 1978-88", International Marketing Review, Vol. 6 No. 4, pp. 7-26.

Acedo, F.J. and Galan, J.L. (2011), "Export stimuli revisited: the influence of the characteristics of managerial decision makers on international behaviour", International Small Business Journal, Vol. 29 No. 6, pp. 648-670.

Andersen, O. (1993), "On the internationalisation process of firms: a critical analysis", Lournal of International Business Studies, Vol. 24 No. 2, pp. 209-231.

Andersson, S. (2011), "International entrepreneurship, born globals and the theory of effectuation", Iournal of Small Business and Enterprise Develobment, Vol. 18 No. 3, pp. 627-643.

Andersson, S. and Floren, H. (2011), "Differences in managerial behaviour between small international and non-international firms", Iournal of International Entrepreneurship, Vol. 9 No. 3, pp. 233-258.

Autio, E., Sapienza, H. and Almeida, J. (2000), "Effect of age at entry, knowledge intensity, and imitability on international growth", Academv of Management Journal, Vol. 43 No. 5, pp. 909-924.

Barney, J.B. (2001), "Is the resource-based 'view' a useful perspective for strategic management research? Yes", Academv of Management Review, Vol. 26 No. 1, pp. 41-56.

Barney, J.B. (2014), "How marketing scholars might help address issues in resource-based theory", Lournal of the Academv of Marketing Science, Vol. 42 No. 1, pp. 24-26.

Bell, J., Crick, D. and Young, S. (2004), "Small firm internationalisation and business strategy: an exploratory study of 'knowledge-intensive' and 'traditional' manufacturing firms in the UK”, International Small Business Iournal, Vol. 22 No. 1, pp. 23-56.

Bilkey, W.J. (1978), "An attempted integration of the literature on the export behaviour of firms", Iournal of International Business Studies, Vol. 9 No. 1, pp. 33-46.

Bushe, G. and Kassam, A.F. (2005), "When is appreciative inquiry transformational? A meta case analysis", Lournal of Aphlied Behavioral Science, Vol. 41 No. 2, pp. 161-181.

Cady, S.H. and Caster, M.A. (2000), "A diet for action research: an integrated problem and appreciative focused approach to organization development", Organization Development Journal, Vol. 18 No. 4, pp. 79-93.

Carson, D., Cromie, S., McGowan, P. and Hill, J. (1995), Marketing and Entrepreneurship in SMEs: An Innovative Approach, Prentice Hall, Hemel Hempstead.
Inquiry into the first export order 
QMR 19,1

98

Coghlan, D. and Brannick, T. (2001), Doing Action Research in your own Organization, Sage Publications, London.

Cooperrider, D. and Srivastva, S. (1987), "Appreciative inquiry in organizational life", in Woodman, R. and Pasmore, W. (Eds), Research in Organizational Change and Development, Jai Press, Greenwich, Vol. 1, pp. 129-169.

Cooperrider, D. and Whitney, D. (1999), Appreciative Inquiry, Berrett-Koehler, San Francisco, CA. Cooperrider, D. and Whitney, D. (2001), "A positive revolution in change", in Cooperrider, D., Sorenson, P., Whitney, D. and Yeager, T. (Eds), Appreciative Inquiry: An Emerging Direction for Organization Development, Stipes, Champaign, IL, pp. 9-29.

Coviello, N.E. and McAuley, A. (1999), "Internationalisation and the smaller firm: a review of contemporary empirical research", Management International Review, Vol. 39 No. 2, pp. 223-257.

Crick, D. and Crick, J. (2014), "The internationalization strategies of rapidly internationalizing high-tech SMEs: planned and unplanned activities", European Business Review, Vol. 26 No. 5, pp. 421-448.

Crick, D. and Crick, J. (2015), “The first export order: a marketing innovation revisited”, Journal of Strategic Marketing. doi 10.1080/0965254X.2014.1001870.

Crick, D. and Jones, M.V. (2000), "Small high technology firms and international high technology markets", Journal of International Marketing, Vol. 8 No. 2, pp. 63-85.

Crick, D. and Spence, M. (2005), "The internationalisation of 'high performing' U.K. high-tech SMEs: a study of planned and unplanned strategies", International Business Review, Vol. 14 No. 2, pp. 167-185.

Durmusoglu, S.S., Apfelthaler, G., Nayir, D.Z., Alvarez, R. and Mughan, T. (2012), "The effect of government-designed export promotion service use on small and medium-sized enterprise goal achievement: a multidimensional view of export performance", Industrial Marketing Management, Vol. 41 No. 4, pp. 680-691.

Eriksson, P. and Kovalainen, A. (2008), Qualitative Methods in Business Research, Sage Publications, London.

Freeman, S., Hutchings, K. and Chetty, S. (2012), "Born-globals and culturally proximate markets”, Management International Review, Vol. 52 No. 3, pp. 425-460.

Freixanet, J. (2011), "Export promotion programs: their impact on companies' internationalization performance and competitiveness", International Business Review, Vol. 21 No. 6, pp. 1065-1086.

Gabrielsson, P. and Gabrielsson, M. (2013), “A dynamic model of growth phases and survival in international business-to-business new ventures: the moderating effect of decision-making logic”, Industrial Marketing Management, Vol. 42 No. 8, pp. 1357-1373.

Hammond, S.A. and Royal, C. (2001), Lessons from the Field: Applying Appreciative Inquiry, Practical Press, Plano.

Ibeh, K. (2003), “Toward a contingency framework of export entrepreneurship: conceptualizations and empirical evidence", Small Business Economics, Vol. 20 No. 1, pp. 49-68.

Jones, M.V. (1999), "The internationalisation of small high-technology firms", Lournal of International Marketing, Vol. 7 No. 4, pp. 15-41.

Jones, M.V. and Coviello, N.E. (2005), "Internationalization: conceptualising an entrepreneurial process of behavior in time”, Lournal of International Business Studies, Vol. 36, pp. 284-303. 
Jones, M.V., Coviello, N.E. and Tang, Y.K. (2011), "International entrepreneurship research (1989-2009): a domain ontology and thematic analysis", Iournal of Business Venturing, Vol. 26 No. 6, pp. 632-659.

Kahiya, E.T. (2013), "Export barriers and path to internationalization: a comparison of conventional enterprises and international new ventures", Iournal of International Entrepreneurshit, Vol. 11 No. 1, pp. 3-29.

Kalinic, I., Sarasvathy, S.D. and Forza, C. (2014), “'Expect the unexpected”: implications of effectual logic on the internationalization process", International Business Review, Vol. 23 No. 3, pp. 635-647.

Kuppusamy, J. and Anantharaman, R.N. (2012), "The link between export performance and export development: does managements' motivation play a role?", Journal of Orgnaizational Management Studies. doi: 10.5171/2012.645053.

Leonidou, L.C. (1995), “Export barriers: non-exporters' perceptions”, International Marketing Review, Vol. 12 No. 1, pp. 4-25.

Leonidou, L.C., Katsikeas, C.S., Palihawadana, D. and Spyropoulou, S. (2007), "An analytical review of the factors stimulating smaller firms to export”, International Marketing Review, Vol. 24 No. 6, pp. 735-770.

Leonidou, L.C., Katsikeas, C.S. and Piercy, N.F. (1998), "Identifying managerial influences on exporting: past research and future directions", Journal of International Marketing, Vol. 6 No. 2, pp. 74-102.

Leonidou, L.C., Palihawadana, D. and Theodosiou, M. (2011), "National export-promotion programs as drivers of organizational resources and capabilities: effects on strategy, competitive advantage, and performance", Lournal of International Marketing, Vol. 19 No. 2, pp. 1-29.

Miesenbock, K.J. (1988), “Small businesses and exporting: a literature review”, International Small Business Journal, Vol. 6 No. 2, pp. 42-61.

Morgan, R.E. (1997), "Export stimuli and export barriers: evidence from empirical research studies", Eurobean Business Review, Vol. 97 No. 2, pp. 68-79.

Murrell, K.L. (1999), "International and intellectual roots of appreciative inquiry", Organization Development Journal, Vol. 17 No. 3, pp. 49-60.

Piercy, N. (1991), Market-Led Strategic Change, Thorsons, London.

Sarasvathy, S.D. (2001), "Causation and effectuation: towards a theoretical shift from economic inevitability to entrepreneurial contingency", Academy of Management Review, Vol. 26 No. 2, pp. 243-263.

Simmonds, K. and Smith, H. (1968), "The first export order: a marketing innovation”, British Journal of Marketing, Vol. 2 No. 2, pp. 93-100.

Sinkovics, R.R. and Alfoldi, E.A. (2012), "Progressive focusing and trustworthiness in qualitative research: the enabling role of computer-assisted qualitative data analysis software (CAQDAS)", Management International Review, Vol. 52 No. 6, pp. 817-845.

Sinkovics, R.R., Penz, E. and Ghauri, P.N. (2005), "Analysing textual data in international marketing research”, Qualitative Market Research: An International Journal, Vol. 8 No. 1, pp. 9-38.

Sinkovics, R.R., Penz, E. and Ghauri, P.N. (2008), "Enhancing the trustworthiness of qualitative research in international business", Management International Review, Vol. 48 No. 6, pp. 689-714.

Stake, R.E. (1995), The Art of Case Study Research, Sage Publications, Thousand Oaks, CA. 
QMR 19,1

Storey, D.J. (1994), Understanding the Small Business Sector, Routledge, London.

Tadajewski, M. (2010), “Critical marketing studies: logical empiricism, 'critical performativity' and marketing practice", Marketing Theorv, Vol. 10 No. 2, pp. 210-222.

Welch, C., Piekkari, R., Plakoyiannaki, E. and Paavilainen-Mantymaki, E. (2011), "Theorising from case studies: towards a pluralist future for international business research", Lournal of International Business Studies, Vol. 42, pp. 740-762.

Welch, D.E. and Welch, L.S. (1996), "The Internationalization process and networks: a strategic management perspective", Lournal of International Marketing, Vol. 4 No. 3, pp. 11-28.

Welch, D.E. and Welch, L.S. (2004), "Broadening the concept of international entrepreneurship: internationalisation, networks and politics", Journal of International Entrepreneurship, Vol. 2 No. 3, pp. 217-234.

Westhead, P., Wright, M. and Ucbasaran, D. (2001), "The internationalisation of new and small firms: a resource-based view", Lournal of Business Venturing, Vol. 16 No. 4, pp. 333-358.

\begin{abstract}
About the authors
Dave Crick is a Professor at Telfer School of Management, University of Ottawa, Ottawa, Canada. He was employed at Victoria University of Wellington when this paper was submitted. His current research interests involve work at the marketing-international-entrepreneurship interface and particularly work that addresses a more effective public-private sector interaction. Dave Crick is the corresponding author and can be contacted at: dcrick@uottawa.ca

James Crick is a Researcher in the Business School at Loughborough University, UK. His current research interests involve work in marketing strategy and international business, particularly work that addresses competitiveness.
\end{abstract}

For instructions on how to order reprints of this article, please visit our website: www.emeraldgrouppublishing.com/licensing/reprints.htm Or contact us for further details: permissions@emeraldinsight.com 